University of Nebraska - Lincoln

DigitalCommons@University of Nebraska - Lincoln

2-15-2005

\title{
Vertical Movement of Water in a High Plains Aquifer Induced by a Pumping Well
}

\author{
Xunhong Chen \\ University of Nebraska - Lincoln, xchen2@unl.edu \\ YanFeng Yin \\ University of Nebraska - Lincoln \\ James W. Goeke \\ University of Nebraska - Lincoln, jgoeke1@unl.edu \\ Robert F. Diffendal \\ University of Nebraska - Lincoln, rdiffendal1@unl.edu
}

Follow this and additional works at: https://digitalcommons.unl.edu/natrespapers

Part of the Hydrology Commons, Natural Resources and Conservation Commons, and the Water Resource Management Commons

Chen, Xunhong; Yin, YanFeng; Goeke, James W.; and Diffendal, Robert F., "Vertical Movement of Water in a High Plains Aquifer Induced by a Pumping Well" (2005). Papers in Natural Resources. 74.

https://digitalcommons.unl.edu/natrespapers/74

This Article is brought to you for free and open access by the Natural Resources, School of at DigitalCommons@University of Nebraska - Lincoln. It has been accepted for inclusion in Papers in Natural Resources by an authorized administrator of DigitalCommons@University of Nebraska - Lincoln. 
Published in Environmental Geology: International Journal of Geosciences 47 (2005), pp. 931-941; doi 10.1007/s00254-005-1223-4

Copyright (C) 2005 Springer-Verlag. Used by permission. http://www.springerlink.com/content/0943-0105

Submitted August 12, 2004; accepted December 6, 2004; published online February 15, 2005.

\title{
Vertical movement of water in a High Plains Aquifer induced by a pumping well
}

\author{
Xunhong Chen,* Yanfeng Yin, J. W. Goeke, and R. F. Diffendal Jr. \\ School of Natural Resources, University of Nebraska-Lincoln, Lincoln, NE 68588, USA \\ * Corresponding author: Xunhong Chen; tel 402 472-0772; fax 402 472-4608; email xchen2@unl.edu
}

\begin{abstract}
Field observation and numerical simulations were carried out to evaluate the hydraulic relationship between the shallow and deep aquifer of a High Plains Aquifer system, in which shallow and deep aquifers are separated by an aquitard. Pumping from the lower aquifer resulted in a small drawdown in the upper aquifer and a larger drawdown in the aquitard; pumping from the shallow aquifer caused a small drawdown in the aquitard and the deep aquifer. Analysis of pumping test data gives the values of the hydraulic conductivity of the aquitard and the deep aquifer. Long-term observation of groundwater levels in the shallow and deep aquifers showed that a strong downward hydraulic gradient was maintained during an irrigation season. Numerical simulations were used to calculate the induced leakage of water from the shallow to the deep aquifer. Water budget analyses suggested that after pumping continues for a couple of days, the leakage from the overlying layers begins to supply the majority of the withdrawal from the deep aquifer. However, the induced leakage from the upper shallow aquifer can travel only a few meters into the aquitard, and it can not reach the lower aquifer during a 90 day pumping period. The major portion of the induced leakage occurred during the pumping period, but a small leakage can continue as a residual effect after the pumping period. The vertical hydraulic conductivity of the aquitard plays a major role in partitioning the ratio of the induced leakage for the pumping and after-pumping periods.
\end{abstract}

Keywords: induced groundwater leakage, aquifer-aquitard, hydraulic conductivity, High Plains Aquifer, Nebraska, USA

\section{Introduction}

The High Plains Aquifer (HPA), extending from South Dakota to western Texas, is the largest aquifer in the United States, and has an area of 450,600 $\mathrm{km}^{2}$ (U.S. Geological Survey 2002). Each year, a significant volume of water is extracted from the aquifer for agricultural irrigation and other uses. Annual groundwater pumpage from this aquifer for irrigation was around 23,427 million $\mathrm{m}^{3}$ in 1974-1995 (McGuire et al. 2003). As a result, water level decline in some areas has caused significant adverse impacts on the surface water systems, for example, depleting streamflow. Application of chemicals for agricultural development resulted in another environmental problem by elevating the levels of non-point source contaminants, particularly in the shallow parts of the aquifer. Engburg and Spalding (1978) reported that the concentration of nitrate in Nebraska's groundwater can be as high as $200 \mathrm{mg} / \mathrm{l}$.

In the Platte River Valley of south-central Nebraska, the HPA system consists of three parts: the shallow allu- 
vial aquifer, the deep Ogallala Group, and an aquitard that separates the two aquifers. A significant number of irrigation wells and center pivot irrigation systems have been constructed in this area for agricultural development. In some counties, the density of irrigation wells is over 3.4/ $\mathrm{km}^{2}$ (Flowerday and others 1998). Most irrigation wells are constructed in the shallow alluvial aquifer, but some are in the deep aquifer including domestic wells which are constructed for drinking water supplies. According to a report by the Nebraska Management Systems Evaluation area (MSEA) project, the groundwater in the shallow aquifer has a high concentration of nitrate-nitrogen. The study of Ayers et al. (1998) showed that the concentration of nitrate-nitrogen in the alluvial aquifer was as high as $43 \mathrm{mg} /$ l. Induced leakage of low-quality water from the shallow aquifer into the deep aquifer threatens the quality of the drinking water source.

For water quality issues, an aquitard is often considered a geological barrier that may impede the movement of contaminants. The vertical hydraulic conductivity of the aquitard may be a key parameter in the analysis of hydraulic connectivity between the shallow and deep aquifer. However, the hydraulic properties of the aquitard have not been determined in this area; as well as its role as a hydraulic barrier to allow leakage is poorly understood.

Among the methods for determination of aquifer-aquitard hydraulic properties and relationship, pumping tests are considered one of the best methods in the characterization of hydrogeologic systems. While results of the hydraulic properties for the shallow aquifer have been reported by Ayers et al. (1998), Zlotnik and Zurbuchen (1998), McGuire and Kilpatrick (1998), and Chen et al. (2003), data are particularly scarce for the aquitard and deep part of the HPA, i.e., the Ogallala Group, which is the major unit of the HPA.

Butler and Tsou (2003) presented an analytical method to calculate leakage induced by a pumping well. Their solution was based on the leaky aquifer model of Hantush and Jacob (1955), which includes the following assumptions: a fully penetrating pumping well, zero storage in the aquitard (confining layer), and constant head in the aquifer above the confining layer. Their simulation results suggest that $100 \%$ of extraction from the confined aquifer will eventually come from the shallow aquifer. However, they did not attempt to analyze the travel time of the induced leakage from the shallow aquifer to deep aquifer.

The first purpose of this study was to determine the hydraulic relationship between the shallow and the deep aquifer system. An observation well network was constructed in the shallow and deep aquifer, and in the aquitard, to monitor the response of hydraulic head to pumping in the shallow and deep aquifers. Observation was made in short-term pumping tests and in irrigation and after-irrigation seasons.
The second purpose was to determine the leakage of shallow groundwater induced by pumping in the deep wells. The authors evaluated the role of a number of hydrologic parameters which controls the magnitude of induced leakage.

\section{Methods}

Figure 1 shows the schematic HPA system at the test site of the Nebraska Management Systems Evaluation Area in south-central Nebraska. The thickness of the shallow alluvial deposits (for both saturated and unsaturated parts) is about $18.3 \mathrm{~m}$, and the deeper Ogallala Group is about $25.3 \mathrm{~m}$. The aquitard is about $9.1 \mathrm{~m}$. The alluvium consists of Quaternary alluvial sand and gravel deposits. The Ogallala Group consists of Tertiary greenish-tinted sands and gravels as well as sandstone and siltstone. The aquitard is composed of silts and clays. The Late Cretaceous Pierre Shale regionally underlies the Ogallala Group. It is considered to be the impermeable base of the deep confined aquifer.

Twelve observation wells were installed in July 1999 at the study site for groundwater-level monitoring. Eight wells (prs01, prs02, prs05, prs06, prs07, prs08, prs11, and prs12; Platte River study (PRS)) were constructed in the shallow alluvial aquifer; two wells (prs03 and prs09) were constructed in the deep aquifer; and another two wells (prs04 and prs10) were constructed in the aquitard (Figure 1). These observation wells consist of $5 \mathrm{~cm}$ diameter PVC casing and screen. A length of $0.9 \mathrm{~m}$ screen with $0.025 \mathrm{~cm}$ slot size was used at the bottom of each observation well. Immediately above the screen, a bentonite plug was used to seal the screen from the rest of the borehole. Sediment samples were collected from drilling cuttings for each $1.5 \mathrm{~m}$ interval of borehole, or when lithologic differences were encountered. Resistivity logs prepared for wells prs03 and prs09 (Figure 2) show the three-layered aquiferaquitard system.

After the completion of the observation wells, pressure transducers were installed in shallow and deep observation wells (prs08 and prs09) to monitor hourly groundwater levels. Hydraulic head in the deep aquifer was several $\mathrm{cm}$ higher than the head in the shallow alluvial aquifer. Two existing irrigation wells, one in the alluvium, and the other in the Ogallala, were available at the study site as pumping wells (Figure 1). Both wells are partially screened and only $6 \mathrm{~m}$ apart.

Irrigation in this area typically occurs from June to August. Before the beginning of a pumping test, care was taken to be sure that the water level was stable and that the recharge to the aquifer (or return flow) from irrigation was negligible. Water levels at wells prs08 and prs09 indicated that the groundwater system had stabilized in late October 1999. The pumping test in the deep aquifer continued 
Figure 1 Sketch map of the High Plains Aquifer near Shelton, Buffalo County, central Nebraska.

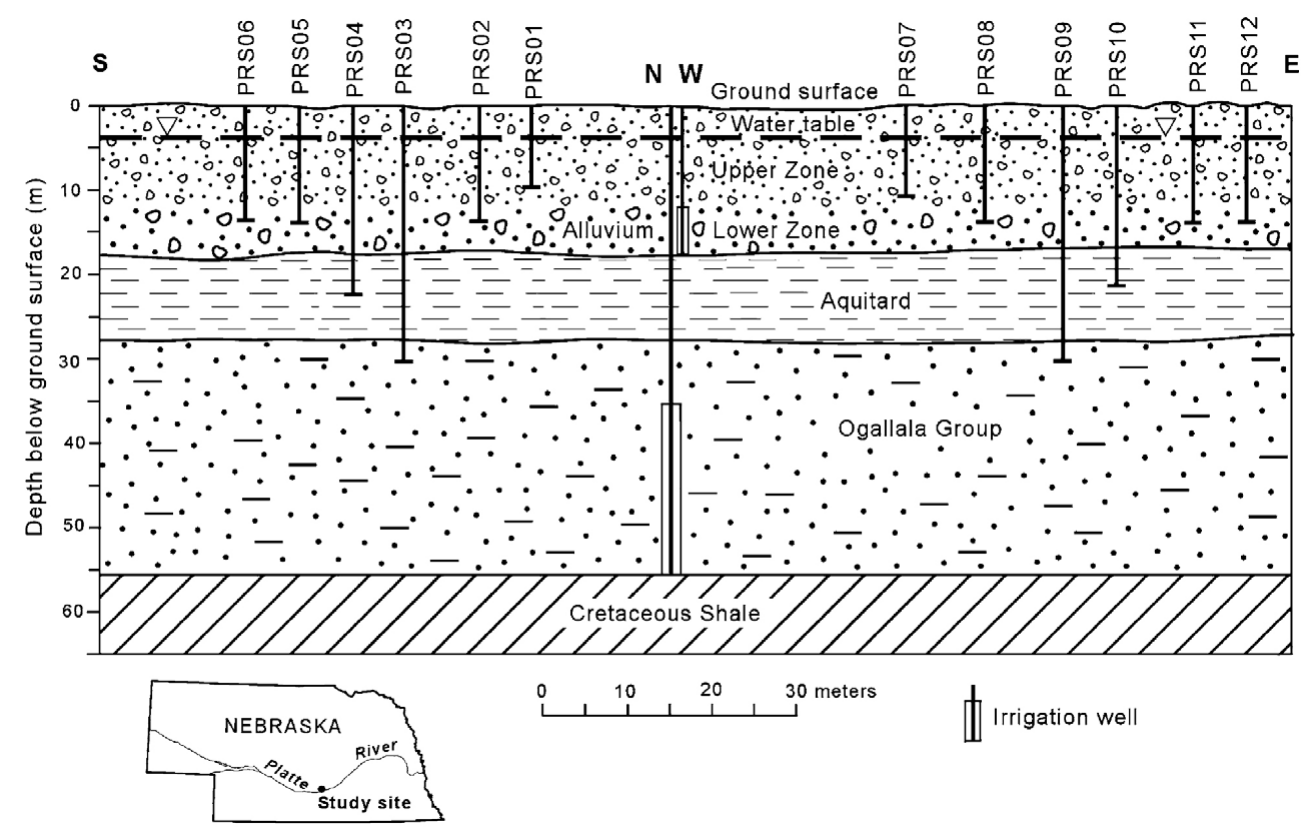

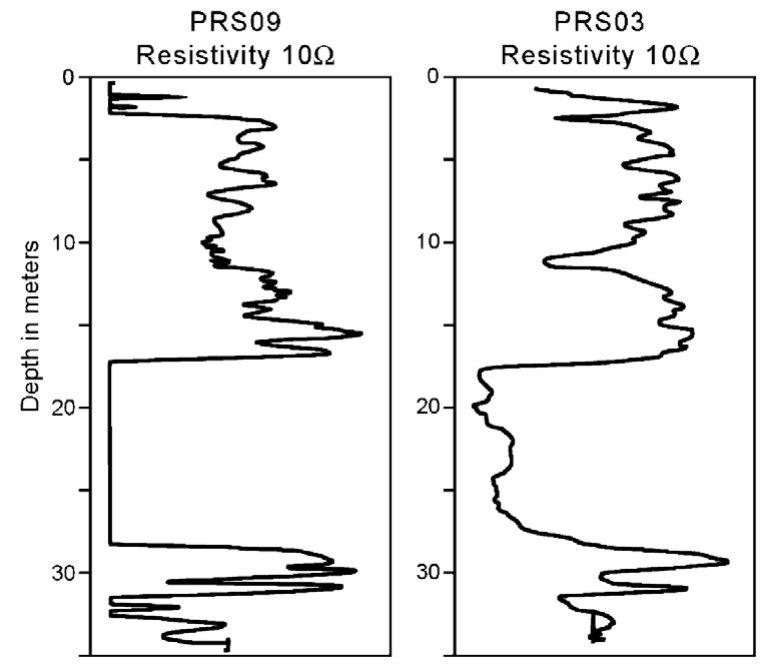

Figure 2 Resistivity logs for wells prs03 and prs09. A distinct change occurs at a depth about $12.2 \mathrm{~m}$ below the ground surface.

for $48 \mathrm{~h}$ between 12:30 p.m. on 8 November 1999 and 12:30 p.m.10 November 1999, with an average pumping rate of $113.5 \mathrm{~m}^{3} / \mathrm{h}$. Groundwater levels were recorded from the 12 wells. The pumping well has a $17 \mathrm{~m}$ screen in the lower part of the Ogallala aquifer. During the test, the extracted groundwater was delivered through irrigation pipe to a ditch about $300 \mathrm{~m}$ from the pumping well. After pumping stopped, the data logger remained at these wells for 5 days monitoring the recovery process in the aquifer-aquitard system.

A $26 \mathrm{~h}$ pumping test was conducted in the shallow aquifer. The pumping rate was $170.3 \mathrm{~m}^{3} / \mathrm{h}$. The shallow aquifer was in an unconfined condition and the pumping from this aquifer resulted in a small drawdown. Drawdown was also observed in the aquitard and deep aquifer. Figure 3 shows drawdown curves for three wells (prs08, prs09, and prs10), installed respectively in the shallow and deep aquifer, as well as in the aquitard. The maximum drawdown was $0.88 \mathrm{~m}$ at well prs08 (in the shallow alluvial aquifer), $6.9 \mathrm{~cm}$ in the aquitard (well prs09), and $0.55 \mathrm{~cm}$ in the deep aquifer (well prs10).

\section{Results and discussions}

\section{Hydraulic relationship between the alluvial aquifer and Ogallala aquifer}

Figure 4 shows the time-drawdown curves of six observation wells for the pumping test in the deep Ogallala aquifer. The groundwater level in the deep aquifer declined very fast after pumping began. After 240 min pumping, the drawdown at well prs09 was $5.55 \mathrm{~m}$. The drawdown at well prs03 was $8.03 \mathrm{~m}$ at the end of pumping. Drawdown in this confined aquifer is much greater than that in the alluvial aquifer and represents a decline of potentiometric surface. A large drawdown at well prs10 (in the aquitard) was also observed and it reached as much as $7.16 \mathrm{~m}$ by the end of pumping (Figure 4). The pressure transducer at well prs10 malfunctioned in the first day of test and drawdown was recorded only between 1,340 min to the end of the test since pumping began. The time-drawdown curve of well prs10 for the recovery period is also presented in Figure 4. 

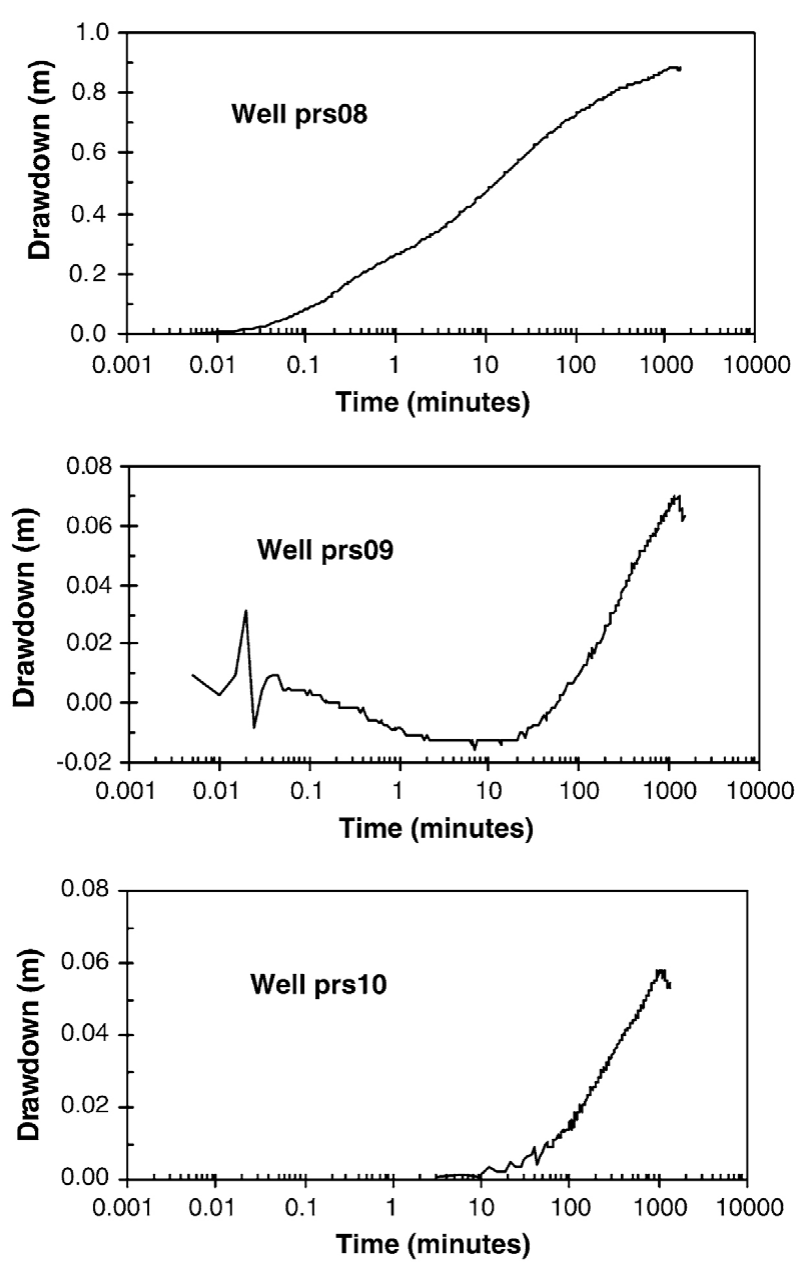

Figure 3 Time-drawdown curves for three observation wells (wells prs08, prs09, and prs10) by pumping water from the shallow alluvial aquifer.

Pumping in the Ogallala aquifer resulted in a small change in water levels in the shallow aquifer. The drawdown observed in the shallow aquifer was negative (rise of the water table) at the early stage of the pumping. This reverse drawdown (Andreason and Brookhart 1963; Hsieh 1996) occurred immediately after pumping began and disappeared between $145 \mathrm{~min}$ and $200 \mathrm{~min}$ in wells prs01, prs02, prs06, prs07, prs08, and prs12 (Time-drawdown curves for prs02, prs06, and prs08 are not presented in Figure 4). The rise in water level during this early period was in inverse proportion to the distance between observation and pumping wells. The largest increase was $2.1 \mathrm{~cm}$ and occurred at well prs01. The time-drawdown curves for wells prs07 and prs12 also showed the reverse drawdown. After the period of reverse drawdown, water levels declined slightly at each of the observation wells (compared to the initial water table prior to the pumping). The drawdown ranged from $6.5 \mathrm{~cm}$ to $8 \mathrm{~cm}$ at the end of the pumping test. Decline of the water table in the alluvium in- dicated that water from the shallow aquifer moved downward. Wells prs07 and prs12 were at the two ends of the west-east transect and about $40 \mathrm{~m}$ apart (see Figure 1), but the magnitude of drawdown was almost the same (see Figure 4). The maximum drawdown was $7.6 \mathrm{~cm}$ for prs07 and 7.5 for prs12.

The reverse drawdown observed in the shallow aquifer is an example of the Noordbergum effect, which has been documented by Andreason and Brookhart (1963) and Rodrigues (1983). According to Kim and Parizek (1997), the Noordbergum effect is caused by two mechanisms: a faster mechanical propogation (deformation) of the pumping stress than its hydraulic propogation (drawdown) from the pumped aquifer into the adjacent aquitard and unpumped aquifer due to relatively lower hydraulic conductivity of the aquitard, and a mechanical amplification in the lower part of the relatively soft aquitard.

At the end of the 5 day recovery period, the groundwater level remained slightly lower in the shallow and deep aquifers. The water level at well prs03 (in confined aquifer) was $2.5 \mathrm{~cm}$ lower than that prior to pumping; it was $2.3 \mathrm{~cm}$ and $2.0 \mathrm{~cm}$ lower at wells prs07 and prs12, both in the shallow aquifer.

Long-term observation has continued at wells prs08, prs09, and prs10 since November 22, 1999. Water levels were recorded for every two hs in these wells. The observation data indicated that the two nearby irrigation wells were pumped intensively during each irrigation season. Figure 5 shows the difference of the hydraulic head between wells prs08 (in the shallow alluvial aquifer) and prs09 (in the Ogallala aquifer). For the periods between the two irrigation seasons, the hydraulic head in the deep aquifer is slightly higher. However, during each of the four irrigation seasons, the drawdown in the Ogallala aquifer was much larger. As a result, a downward flow was generated and maintained in each irrigation season; this leads to a leakage of groundwater crossing the layer boundaries: water migrating from the alluvium to the aquitard and from aquitard to the confined Ogallala aquifer. The curve in Figure 5 indicates that pumping during irrigation was intermittent with much more intensive pumping during the 2002 and 2003 irrigation seasons due to a severe drought in the region. Figure 5 shows several positive head-differences during the irrigation season, which occurred when water was pumped only in the shallow well.

\section{Hydraulic properties of the aquitard and the Ogallala aquifer}

The analytical solution of Hantush (1964) was appropriate for simulation of drawdown in a leaky confined aquifer with a partially screened pumping well. This solution assumes the shallow aquifer as a constant-head boundary. 
Figure 4 Time-drawdown curves for six observation wells (wells prs01, prs03, prs07, prs09, prs10, and prs12) by pumping water from the confined Ogallala group. The horizontal axis is the time since pumping began or since recovery test began for well prs10.
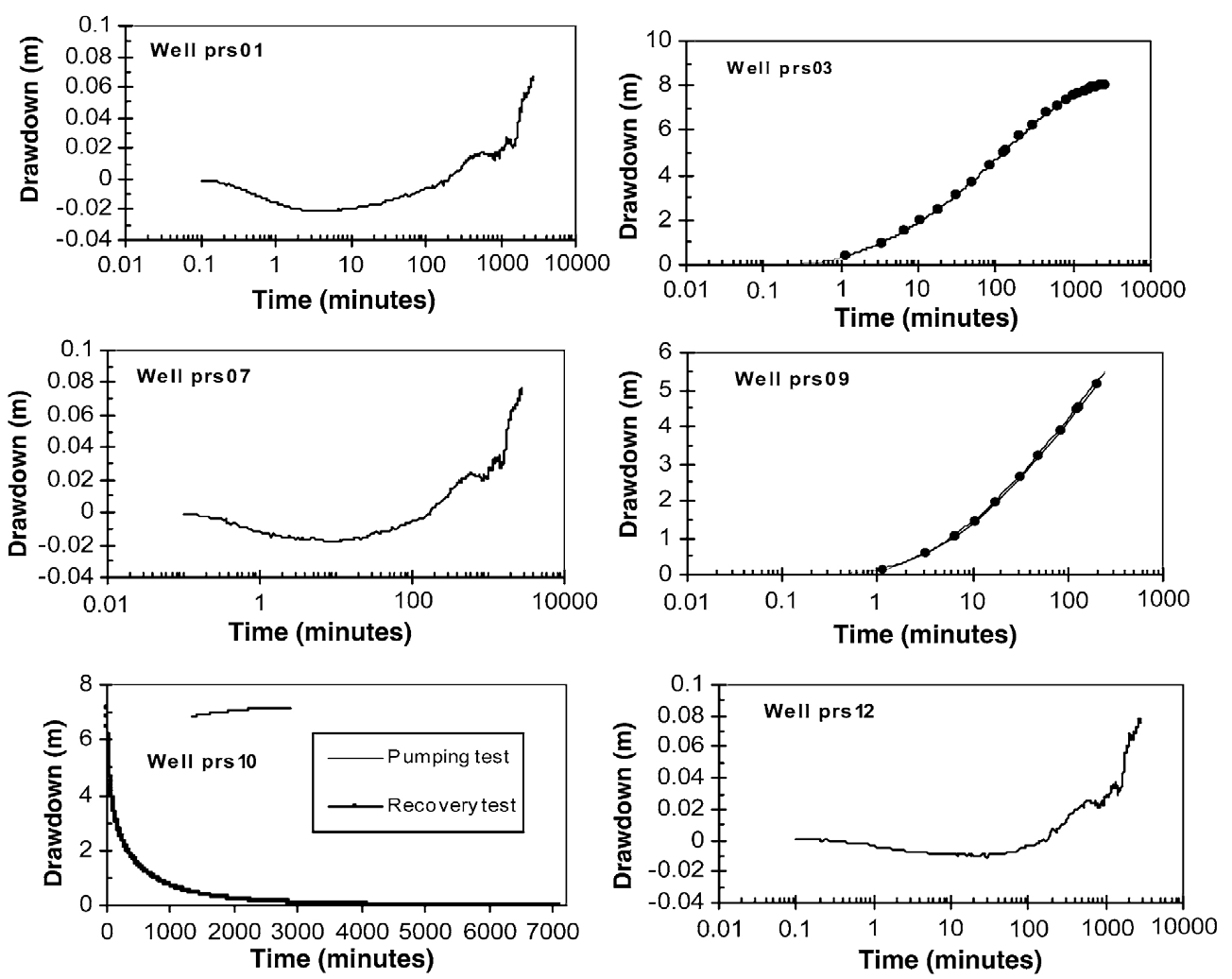

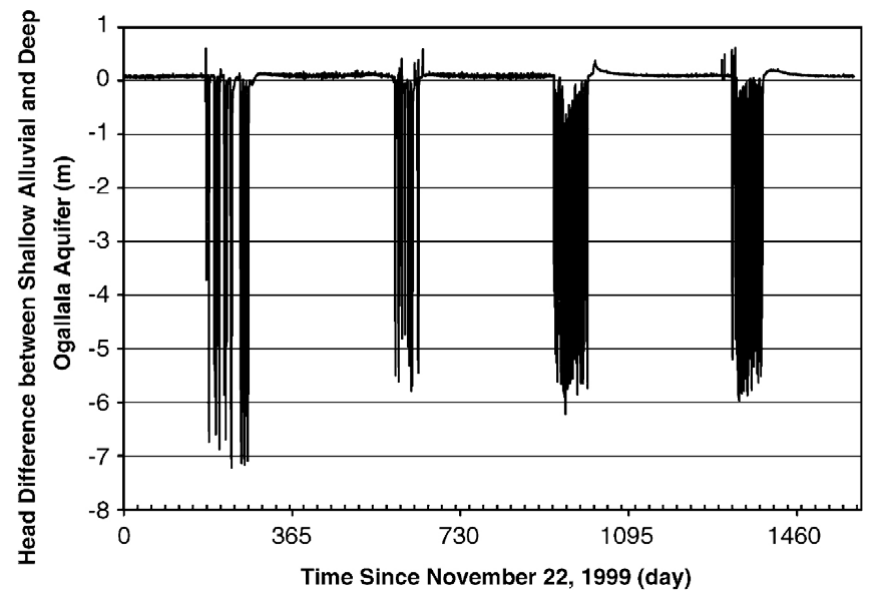

Figure 5 The difference of hydraulic head in the alluvial and Ogallala aquifer during irrigation and non-irrigation periods since 22 November 1999. A negative value indicates a downward hydraulic gradient.

In this pumping test, a small drawdown was observed in the shallow alluvium. To determine the effect of the shallow aquifer on parameter estimation of the aquitard and the deep aquifer, the authors used MODFLOW-2000 (Harbaugh et al. 2000; Hill et al. 2000) for inverse calculation of hydraulic parameters of the aquifer and aquitard. MODFLOW-2000 provides flexibility for simulating more complex hydrologic conditions of an aquifer-aquitard system.
Although MODFLOW-2000 provides researchers a useful tool for solving inverse problems of hydrogeology, utilization of MODFLOW-2000 (or another numerical model) in the analysis of pumping test data requires that a very fine grid spacing must be used near the pumping well to represent observation locations as accurately as possible and that relatively small time steps are needed. As a result, a significant amount of computational time is required for parameter estimation. The inverse method in MODFLOW2000 is based on nonlinear least squares algorithms, which were first applied to groundwater hydrology in the 1960s (Jacquard and Jain 1965; Jahns 1966). Later, the applications became more common for 2-D problems of groundwater flow, leading to the generation of a review paper of the inverse method (Yeh 1986). When the inverse method is coupled with a numerical model, a hydraulic head must be calculated at each node (or cell) of the model domain, although only the generated heads for the observation wells are used in the parameter estimation.

The hydrogeologic system at the study site can be characterized by two highly transmissive horizontal aquifers (shallow alluvial aquifer and deep Ogallala Group) that are separated in the vertical direction by a confining layer of much lower transmissivity. Because pumping from the Ogallala Group led to a large drawdown, a large model 
Figure 6 95\% linear, individual confidence intervals (open square $\square$ ) and estimated values (filled square $\mathbf{a})$ for deep aquifer models. a) Aquitard vertical hydraulic conductivity, b) Ogallala Group: horizontal hydraulic conductivity, c) Ogallala Group: anisotropy; d) Ogallala Group: specific storage.
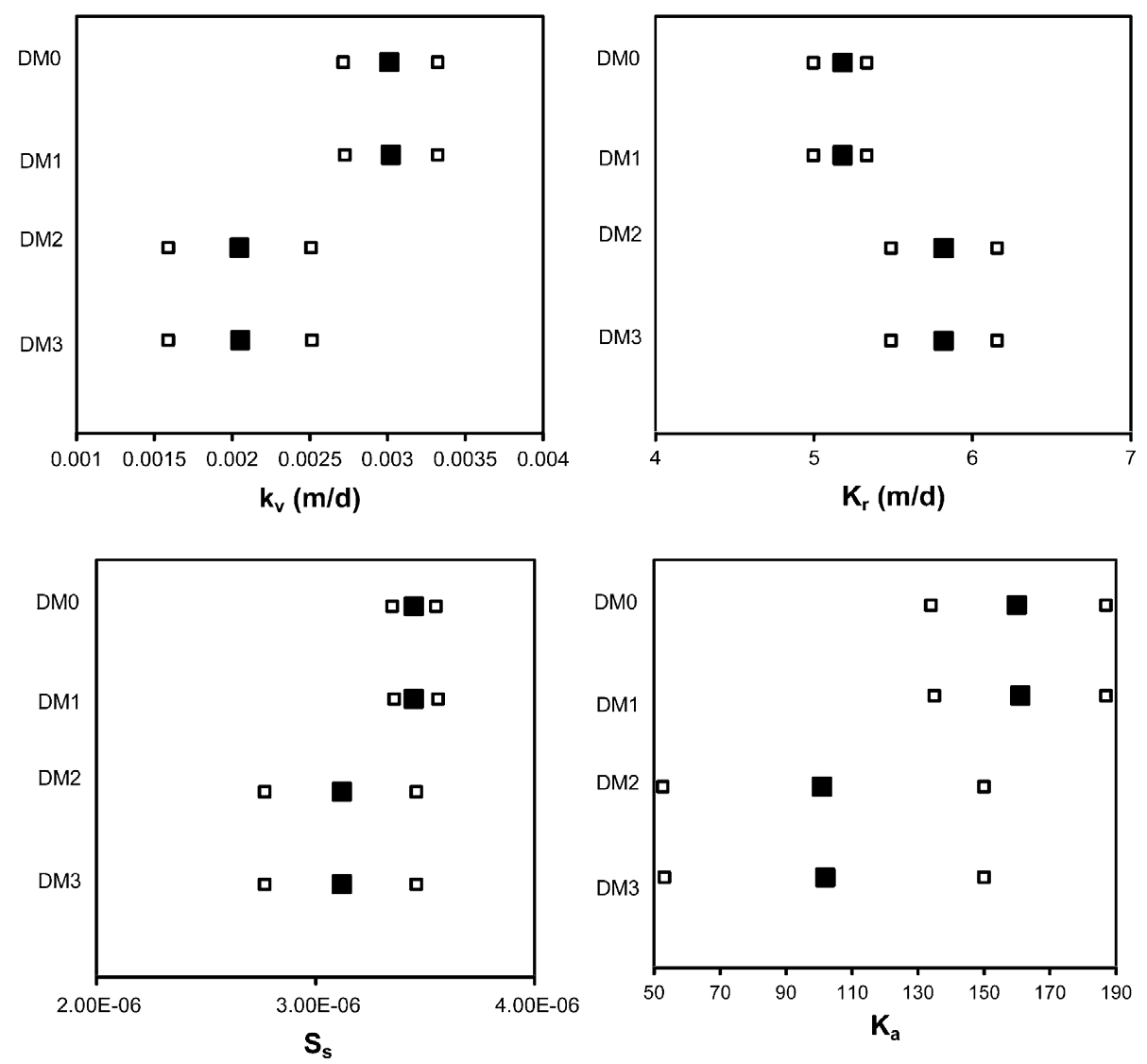

domain was used to minimize the effects of boundaries. In this simulation, the model domain was 7,824 $\times 7,824 \mathrm{~m}$ in the horizontal direction and $48.5 \mathrm{~m}$ in the vertical direction. The domain was divided into 112 rows and 112 columns. The grid size varied from $9.1 \mathrm{~m}$ to $182.9 \mathrm{~m}$. The model included three layers, plus a confining layer. The top layer represented the shallow alluvial aquifer; the other two layers were used to represent the Ogallala Group. The thickness of the top layer (the saturated part of the unconfined aquifer) was $14 \mathrm{~m}$; the confining unit (aquitard) was $9.1 \mathrm{~m}$; and the two layers for the Ogallala Group were 12.65 and $12.65 \mathrm{~m}$, respectively. The pumping well was in the center of the domain and screened from $0 \mathrm{~m}$ to $17.1 \mathrm{~m}$ above the base of the Ogallala aquifer. Domain boundaries were set as constant heads and had no effects on the pumping area.

In the parameter estimation for the aquitard and the Ogallala Group, the overlying alluvium was treated as a constant head boundary in one model and as an unconfined aquifer in the other model. Drawdown data from the two observation wells in the deep aquifer (prs03 and prs09) were used for inverse calculation. Four inverse analyses named DM0 to DM3 were conducted for parameter estimations: DM0 and DM1 using observed data from well prs03; DM2 and DM3 using observed data from both well prs03 and well prs09 (Table 1). DM0 and DM2 treated the shallow aquifer as a constant head; DM1 and DM3 treated the shallow aquifer as a regular aquifer (Table 1). Four unknown parameters were considered: the horizontal hydraulic conductivity $\left(K_{\mathrm{r}}\right)$, aquifer anisotropy $\left(K_{\mathrm{a}}\right)$, and specific storage $\left(S_{\mathrm{s}}\right)$ for the Ogallala Group, as well as the vertical hydraulic conductivity of the aquitard $\left(k_{\mathrm{v}}\right)$. Table 1 is a presentation of these analyses and the identified hydraulic parameters. The strong anisotropy (Table 1 ) suggests that the vertical hydraulic conductivity $\left(=K_{\mathrm{r}} / K_{\mathrm{a}}\right)$ of the Ogallala is from $0.03 \mathrm{~m} / \mathrm{d}$ to $0.06 \mathrm{~m} / \mathrm{d}$. The vertical hydraulic conductivity for the aquitard is even smaller $(0.002-0.003 \mathrm{~m} / \mathrm{d})$. The low hydraulic conductivity in the aquitard indicates that a downward movement of contaminants from the alluvium to the deeper unit may be very slow. The calculated groundwater levels for wells prs03 and prs09 obtained by DM1 are shown in Figure 4 (see the dots).

The $95 \%$ linear individual confidence intervals and the estimated values for deep aquifer analyses were calculated (Figure 6). The authors noticed that among the four parameters, the aquifer anisotropy $\left(K_{\mathrm{a}}\right)$ has a relatively wide confidence interval. The confidence intervals for other three parameters are narrow. 
Table 1 Deep aquifer hydraulic properties obtained by MODFLOW-2000

\begin{tabular}{|c|c|c|c|c|c|c|}
\hline \multirow[t]{2}{*}{ Analysis no. } & \multirow[t]{2}{*}{ Wells } & \multirow[t]{2}{*}{ Top aquifer } & \multicolumn{4}{|l|}{ Estimated value } \\
\hline & & & Aquitard $k_{\mathrm{v}}(\mathrm{m} / \mathrm{d})$ & $K_{\mathrm{r}}(\mathrm{m} / \mathrm{d})$ & $K_{\mathrm{a}}$ & $S_{\mathrm{s}}(1 / \mathrm{m})$ \\
\hline DM0 & Prs03 & Constant head & 0.0030 & 5.18 & 160.49 & $3.453 \times 10^{-6}$ \\
\hline DM1 & Prs03 & Unconfined aquifer & 0.0030 & 5.17 & 161.00 & $3.454 \times 10^{-6}$ \\
\hline DM2 & Prs03\&prs09 & Constant head & 0.0020 & 5.82 & 101.38 & $3.116 \times 10^{-6}$ \\
\hline
\end{tabular}

A model was also developed to consider the aquitard as a regular layer, with horizontal hydraulic conductivity and specific storage treated as unknown parameters in the model. MODFLOW-2000 was also employed in the inverse calculation, but no convergent solution was achieved.

The hydrogeologic system in this study area is a good example of a leaky aquifer (Hantush and Jacob 1955; Hantush 1964): a confined aquifer separated from a shallow aquifer by a confining layer. The Hantush solution (1964) was developed on a series of assumptions for a leaky aquifer, assuming the water table in the unconfined aquifer does not change during pumping. In numerical simulation, if this assumption holds, a constant head boundary can be used to represent the shallow aquifer (the top layer). Analysis DM0 and DM1, DM2 and DM3 are identical pairs except that one treats the shallow aquifer as a constant head and the other treats it as a regular aquifer, where the water table varies with time. Results show that the identified parameters are very close between analyses in a pair. The largest difference of identified parameters is $0.3 \%$, which occurred on deep aquifer anisotropy between analyses DM2 and DM3. This indicates that the assumption of constant head is valid in this study case.

Neuman and Witherspoon (1969) suggested that the assumption of constant head is valid if the transmissivity of the unconfined aquifer is significantly larger than the transmissivity of the confined aquifer, i.e., $T_{\mathrm{UA}}>>T_{\mathrm{CA}}$. In this study case, $T_{\mathrm{UA}}=115.82 \times 14=1,621.5 \mathrm{~m}^{2} /$ day and $T_{\mathrm{CA}}=$ $5.2 \times 25.3=131.6 \mathrm{~m}^{2} /$ day; thus $T_{\mathrm{UA}}=12.3 T_{\mathrm{CA}}$.

\section{Induced groundwater leakage}

As discussed in the introduction section, the intensive use of agricultural chemicals impair the quality of shallow groundwater with nitrate-nitrogen in some areas of the Platte River watershed (Druliner et al. 1996). According to Spalding et al. (2001), the concentration of nitratenitrogen in the shallow aguifer at the study can be $>30 \mathrm{mg} /$ l. One concern is what amount of water will migrate from the shallow aquifer to the aquitard and from the aquitard to the deep confined aquifer, induced by deep well pumping. A numerical model was designed to analyze the induced leakage that occurred in an irrigation season.

The model domain was a square of $19 \times 19 \mathrm{~km}^{2}$. It was divided into 106 rows and 106 columns. In the vertical direction, it was divided into four layers. The upper layer was unconfined, the next layer was an aquitard, and the confined aquifer had two layers. An aquitard of $9.1 \mathrm{~m}$ thick underlies a shallow alluvial aquifer of $14 \mathrm{~m}$ thick; a deep confined aquifer was $25.3 \mathrm{~m}$ thick. Hydraulic parameters were: for the shallow aquifer, $K_{\mathrm{r}}=116 \mathrm{~m} / \mathrm{d}, K_{\mathrm{a}}=90, S_{\mathrm{S}}=6.0 \times 10^{-}$ ${ }^{4} 1 / \mathrm{m}, S_{\mathrm{y}}=0.22$; for the aquitard, $k_{\mathrm{v}}=0.0003$ and $0.003 \mathrm{~m} /$ $\mathrm{d}$ for separate simulations, $s_{\mathrm{s}}=1 \times 10^{-7} 1 / \mathrm{m}$; for the deep confined aquifer, $K_{\mathrm{r}}=6$ and $12 \mathrm{~m} / \mathrm{d}$ in separate simulations, $K_{\mathrm{z}}=1 \mathrm{~m} / \mathrm{d}$, and $S_{\mathrm{s}}=2.4 \times 10^{-5} 1 / \mathrm{m}$. Note that aquitard storage was considered in the model. Initial hydraulic head was assumed to be the same for the shallow aquifer, the aquitard and the deep aquifer. Pumping rate was $113.5 \mathrm{~m}^{3} /$ h. The pumping duration was 90 days, which was close to the length of an irrigation season. The pumping schedule consisted of (1) continuous pumping for 90 days, (2) a 5-day pumping followed by a 5-day non-pumping period in sequence for the 90 day period, and (3) a series of a 7day pumping followed by a 3-day non-pumping period for the 90 day period. Simulation time was 365 days; after the pumping period, a 275-day non-pumping period was also simulated.

MODFLOW 2000 (Harbaugh et al. 2000) was used to simulate the aquifer-aquitard systems; ZONEBUDGET (Harbaugh 1990) was used to calculate the groundwater flow rate and flow volume from shallow aquifer to aquitard and from aquitard to the Ogallala aquifer.

The effects of a number of hydrologic parameters on the level of induced leakage were analyzed. These parameters included the magnitude of vertical hydraulic conductivity of the aquitard, the horizontal hydraulic conductivity of the aquifer, the placement position of the well screen, and the pumping schedule (continuous pumping vs. intermittent pumping). Two indicators were used to reflect the magnitude of the hydraulic connectivity between shallow and 
deep aquifers: leakage rate and leakage volume. The leakage rate was the volume of water crossing the layer boundary per unit time divided by the pumping rate. The leakage volume was the ratio of the total amount of water crossing the layer boundary to the total pumpage for the whole pumping period.

Figure 7 shows that the leakage rate varies during a 90 day pumping period. For the vertical hydraulic conductivity $k_{\mathrm{v}}=0.003 \mathrm{~m} / \mathrm{d}$ (Figure $7 \mathrm{a}$ ), the leakage rate reaches a nearly constant rate $(92.8 \%)$ only 5 days after pumping begins. At the end of the pumping period, the leakage rate is $99.7 \%$. The leakage rate from the shallow aquifer to the aquitard is nearly the same as the leakage from aquitard to the deep aquifer. The residual leakage that occurs after pumping stops is very small; it is only $1.7 \% 30$ days after pumping stops.

When the $k_{\mathrm{v}}$ value of the aquitard was reduced to $0.0003 \mathrm{~m} / \mathrm{d}$ (Figure $7 \mathrm{~b}$ ), the leakage rate was $24.2 \% 5$ days after pumping had begun; it reached $95.4 \%$ for pumping time $=90$ days. For this case, the leakage rate from shallow aquifer to aquitard was also nearly the same as the leakage rate from aquitard to deep aquifer. After pumping was stopped for 30 days, the residual leakage rate was $15.6 \%$. The product of leakage rate and a time interval yields the leakage volume for a given time. Summation of the leakage volume for the entire pumping period gives the total leakage volume.

The storage of the deep aquifer and the aquitard's vertical hydraulic conductivity are two important parameters affecting water supply for the pumpage. Figure 8 shows the
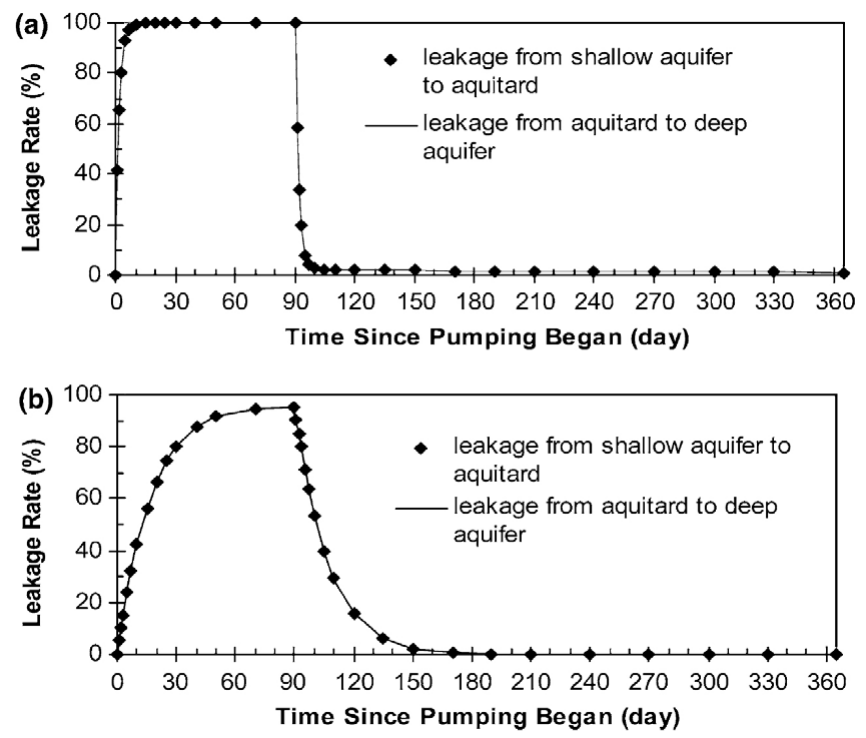

Figure 7 The induced leakage occurred in pumping period and in the after-pumping period. a) The vertical hydraulic conductivity of the aquitard = $0.003 \mathrm{~m} / \mathrm{d}, \mathbf{b}$ ) the vertical hydraulic conductivity of the aquitard $=0.0003 \mathrm{~m} / \mathrm{d}$. curves of normalized sensitivity coefficients of $\left(\partial_{\mathrm{s}} / \partial S_{\mathrm{s}}\right) S_{\mathrm{s}}$ and $(\partial \mathrm{s} / \partial B) B$, where $s$ is the drawdown in the deep aquifer, $S_{\mathrm{s}}$ is the storativity of the aquifer, and $B$ is the square root of the leakage factor $B^{2}$ that is the function of the transmissivity $(T)$ of the deep aquifer and the thickness $(b)$ and the vertical hydraulic conductivity $\left(k_{\mathrm{v}}\right)$ of the aquitard $\left(B^{2}\right.$ $\left.=b T / k_{\mathrm{v}}\right)$. Figure 8a shows the normalized sensitivity curves for $S_{\mathrm{s}}$ and $B$ in which $k_{\mathrm{v}}=0.003 \mathrm{~m} / \mathrm{d}$. This figure suggests that the storage of the deep aquifer $\left(S_{s}\right)$ played a major role only in the first few days of pumping (the value of $\left(\partial s / \partial S_{s}\right) S_{s}$ approaches zero). After this initial time, the leakage factor ( $k_{\mathrm{v}}$ affects the leakage) played a dominant role in supplying water for the pumpage. When $k_{\mathrm{v}}$ was reduced to $0.0003 \mathrm{~m} / \mathrm{d}$ (Figure $8 \mathrm{~b}$ ), the role of storage release from the deep aquifer continued to be important 4 days after pumping began, although at this same time, the $k_{\mathrm{v}}$ had also played an important role in supplying water for the pumpage. The continued role of aquifer storage was because the hydraulic connectivity between shallow and deep aquifer is poor for this case. The results in Figure $8 \mathrm{~b}$ are in an agreement with the results shown in Figure $7 \mathrm{~b}$ where the maximum leakage rate was $95.4 \%$ at pumping time $=$ 90 days; the rest of the leakage rate must come from aquifer storage.
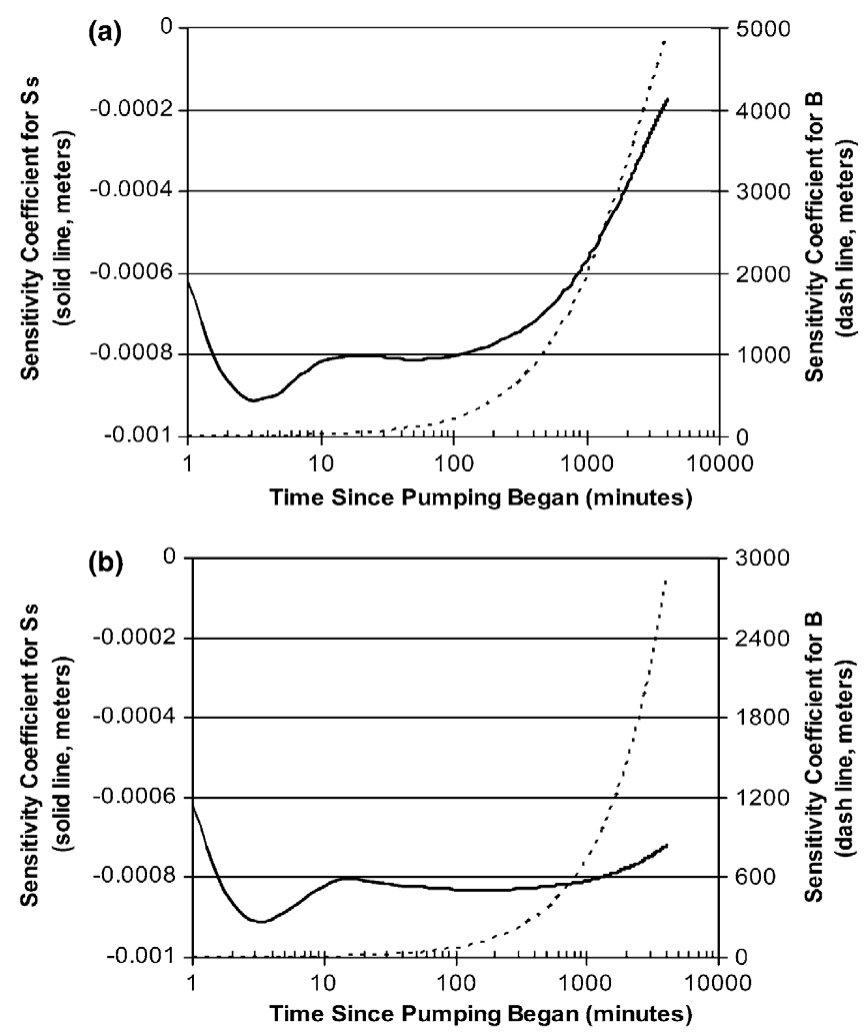

Figure 8 The sensitivity of drawdown in the deep aquifer to aquifer storage (solid line) and to the vertical hydraulic conductivity of the aquitard (dashed line). a) The vertical hydraulic conductivity of the aquitard $=0.003 \mathrm{~m} / \mathrm{d}$ and $\left.S_{\mathrm{s}}=2.4 \times 10^{-5} \mathrm{l} / \mathrm{m}, \mathbf{b}\right)$ the vertical hydraulic conductivity of the aquitard = $0.0003 \mathrm{~m} / \mathrm{d}$ and $S_{\mathrm{s}}=2.4 \times 10^{-5} \mathrm{l} / \mathrm{m}$. 
Table 2 summarizes the leakage volume for a number of simulations. Among these, two $k_{\mathrm{v}}$ values for the aqui$\operatorname{tard}\left(k_{\mathrm{v}}=0.0003 \mathrm{~m} / \mathrm{d}\right.$ and $\left.0.003 \mathrm{~m} / \mathrm{d}\right)$ were used. Two $K_{\mathrm{r}}$ values were used for the confined aquifer; and three pumping schemes were used: continuous pumping for 90 days; 7-day pumping followed by 3-day non-pumping; and 5-day pumping followed by 5-day non-pumping. The results in Table 2 and Figure 7 suggest the following:

1. The hydraulic conductivity in aquitard $\left(k_{\mathrm{v}}\right)$ plays an important role in affecting the level of induced leakage during the 90 day pumping period. A larger $k_{\mathrm{v}}$, providing a better hydraulic connectivity to the deep confined aquifer, results in a larger leakage. This is the same for continuous and intermittent pumping schemes.

2. The magnitude of horizontal hydraulic conductivity $\left(K_{\mathrm{r}}\right)$ of the deep confined aquifer has minor effects on leakage volume when $k_{\mathrm{v}}=0.003 \mathrm{~m} / \mathrm{d}$. However, for $k_{\mathrm{v}}=0.0003 \mathrm{~m} / \mathrm{d}$, effects of the deep confined aquifer hydraulic conductivity on leakage become more apparent. As shown in Table 2, the leakage volume is larger for a smaller $K_{\mathrm{r}}$. This is because a smaller $K_{\mathrm{r}}$ creates a smaller radius for the cone of depression with a larger drawdown. Their combined effect gives a lower level of storage release from the aquifer. As a result, more water comes from the overlying layers.

3. For a given hydrologic system, a continuous or intermittent pumping scheme affects only slightly the volume of induced volume.

Three simulations were conducted based on three depths of pumping well in the Ogallala aquifer: pumping well screen placed at the upper part, middle part, and lower part of the aquifer. Results indicated that the placement of well screens at different depths did not affect the induced leakage.

The authors also simulated the effects of initial hydraulic head on the leakage. In the above-discussed simulations, the hydraulic head in the shallow and deep aquifer was the same. In another simulation, the hydraulic head in the deep aquifer was $5 \mathrm{~cm}$ higher. The hydraulic head for the aquitard in each simulation was the same as that in the deep aquifer. The leakage rate was $4.4 \%$ larger for the former than that for the latter for $k_{\mathrm{v}}=0.003 \mathrm{~m} / \mathrm{d}$ at the end of the first pumping day. This difference became smaller and smaller as pumping continues; (2) in contrast, if $k_{\mathrm{v}}=$ $0.0003 \mathrm{~m} / \mathrm{d}$, there was no major difference between the simulation results at the early pumping time.

The observation well prs10 showed a large drawdown in the aquitard. However, a detailed hydraulic head distribution within the aquitard was not measured during the pumping tests. The observation data were used at well prs10 for an estimation of travel time. At the end of this pumping test, the drawdown at this well was $7.16 \mathrm{~m}$. The well was about $3 \mathrm{~m}$ below the top of aquitard. Thus, the downward hydraulic gradient for this part of the aquitard can be estimated. Assuming effective porosity $=0.1$ and given the estimated $k_{\mathrm{v}}=0.003 \mathrm{~m} / \mathrm{d}$, groundwater velocity was calculated, based on Darcy's Law, to be $0.071 \mathrm{~m} / \mathrm{d}$. For a 90 day continuous pumping, the front of the induced leakage from the shallow aquifer would travel $6.4 \mathrm{~m}$ assuming no dispersion. If the effective porosity is doubled, the traveled distance in the aquitard will be only $3.2 \mathrm{~m}$. These distances are shorter than the thickness of the aquitard $(9.1 \mathrm{~m})$. The water that had moved into the aquitard can move upward or downward during the post-irrigation periods, depending on the direction of the hydraulic gradient. If the leaked water remained in the aquitard, it could be induced into the deep aquifer after one or more irrigation seasons. After the leaked water has arrived at the deep aquifer, it will again take a relatively long time to arrive at the well which is screened only in the lower part of the aquifer given the low vertical hydraulic conductivity of the Ogallala aquifer. Detailed particle tracking analysis to determine travel times and pathlines from the shallow aquifer to the well screen of the deep pumping well can be carried out using a particle tracking method such as MODPATH (Pollock 1989).

\section{Summary and conclusions}

Pumping test results indicated that the shallow alluvial aquifer and the deep Ogallala aquifer, separated by an aquitard, are hydraulically connected. During non-pumping periods, migration of water from the shallow aquifer to the deep aquifer is very unlikely because a downward flow

Table 2 Total leakage volume (\%) from aquitard to deep aquifer under various pumping schedules and hydraulic parameters

\begin{tabular}{|c|c|c|c|c|}
\hline Vertical hydraulic conductivity of aquitard & $k_{\mathrm{v}}=0.003$ & & $k_{\mathrm{v}}=0.000$ & \\
\hline Horizontal hydraulic conductivity of deep aquifer & $K_{\mathrm{r}}=6 \mathrm{~m} / \mathrm{d}$ & $K_{\mathrm{r}}=12 \mathrm{~m} / \mathrm{d}$ & $K_{\mathrm{r}}=6 \mathrm{~m} / \mathrm{d}$ & $K_{\mathrm{r}}=12 \mathrm{~m} / \mathrm{c}$ \\
\hline Continuous pumping for 90 days (\%) & 97.8 & 96.7 & 75.6 & 66.2 \\
\hline $\begin{array}{l}\text { Intermittent pumping: } 5 \text { day pumping } \\
\text { followed by } 5 \text { day non-pumping in } 90 \text { days (\%) }\end{array}$ & 98.8 & 97.3 & 73.7 & 62.2 \\
\hline Intermittent pumping: 7 day pumping & 094 & 081 & 748 & 646 \\
\hline
\end{tabular}


was not observed and there exists an aquitard layer of a relatively low hydraulic conductivity.

Long-term observation indicated that during the irrigation season, a very strong downward hydraulic gradient between the shallow and deep aquifers is caused by seasonal pumping. The reduction in head in the Ogallala aquifer induces a downward movement of water from the shallow aquifer to the aquitard and from the aquitard to the deep aquifer.

Sensitivity analysis and numerical simulations indicated that the induced leakage is the major source supplying pumpage from the deep aquifer during an irrigation season. A major part of the leakage occurred during the pumping period; a small portion occurred as residual leakage after pumping stopped. The magnitude of the vertical hydraulic conductivity of the aquitard is an important parameter controlling the leakage; it also affects the amount of residual leakage.

Although the shallow aquifer is the major source of water for the extraction from the deep aquifer, it is very unlikely that the leaked shallow water can arrive at the pumping well screened in the lower part of the deep aquifer within one irrigation season. This is because the movement of water in the aquitard will be very slow. During an irrigation season, the leaked water from the shallow aquifer could migrate only a few meters into the aquitard. However, repeated pumping during each irrigation season in the deep aquifer can eventually induce shallow groundwater to the deep aquifer.

\section{Acknowledgments}

The research was supported by the US Geological Survey, Conservation and Survey Division, and the Water Center of the University of Nebraska-Lincoln. C. Flowerday edited the manuscript. D. Gosselin and J. Szilagyi reviewed the manuscript. Dee Ebbeka and Ann Mack drafted several figures. This paper is assigned as Journal Series No. 14269, Agricultural Research Division, University of Nebraska-Lincoln

\section{References}

Ayers JF, Chen XH, Gosselin D (1998) Behavior of nitrate-nitrogen movement around a pumping high-capacity well: a field example. Ground Water 36(2):325-337

Andreason GE, Brookhart JW (1963) Reverse water-level fluctuations. In: Bentall R (ed) Methods of collecting and interpreting ground-water data. US Geological Survey Water-Supply Paper 1544-H, pp 30-35

Butler JJ Jr, Tsou MS (2003) Pumping-induced leakage in a bounded aquifer: an example of a scale-invariant phenomenon. Water Resources Res 39(12):2-1-2-8
Chen XH, Goeke J, Ayers J, Summerside S (2003) Observation well network design for pumping tests in unconfined aquifers. J Am Water Resources Assoc 39(1):17-32

Druliner AD, Chen H H, McGrath TS (1996) Relations of nonpointsource nitrate and atrazine. US Geological Survey Water-Resources Investigations Report 95-4202, 51p

Engberg RA, Spalding RF (1978) Groundwater Quality Atlas of Nebraska. University of Nebraska-Lincoln Conservation and Survey Division Resource Atlas No. 3, 39 p

Flowerday CA, Kuzelka RD, Pederson DP (Compilers) (1998) The Groundwater Atlas of Nebraska, 2nd edn. University of Nebraska-Lincoln conservation and Survey Division Resource Atlas No. 4a, 44p

Hantush MS, Jacob CE (1955) Non-steady radial flow in an infinite leaky aquifer. Trans Am Geophys Union 36:95-100

Hantush MS (1964) Hydraulics of wells. Advances in hydro-science. Academic, New York

Harbaugh AW (1990) A computer program for calculating subregional water budgets using results from the US Geological Survey modular three-dimensional ground-water flow model: US Geological Survey Open-File Report 90-392, 46 pp

Harbaugh AW, Banta ER, Hill MC, McDonald MG (2000) MODFLOW-2000, the US Geological Survey Modular Ground-Water Model: User guide to modularization concepts and the groundwater flow process. US Geological Survey Open-File Report 0092, $121 \mathrm{pp}$

Hill MC, Banta ER, Harbaugh AW, Anderman ER (2000) MODFLOW-2000, the US Geological Survey Modular Ground-Water Model: User guide to the observation, sensitivity, and parameter-estimation processes and three post-processing programs. US Geological Survey Open-File Report 00-184, 209 pp

Hsieh PA (1996) Deformation-induced changes in hydraulic head during groundwater withdrawal. Ground Water 34(6):1082-1089

Jacquard P, Jain C (1965) Permeability distribution from field pressure data. Trans Soc Pet Eng 5(4):281-294

Jahns HO (1966) A rapid method for obtaining a two-dimensional reservoir description from well pressure response data. Trans Soc Pet Eng 237:315-327

Kim JM, Parizek RR (1997) Numerical simulation of the Noordbergun effect resulting from groundwater pumping in a layered aquifer system. J Hydrol 202(1-4):231-243

McGuire VL, Kilpatrick JM (1998) Hydrogeology in the vicinity of the Nebraska management systems evaluation area site, central Nebraska. US Geological Survey Water-Resources Investigations Report 97-4266

McGuire VL, Johnson MR, Schieffer RL, Stanton JS, Sebree SK, Verstraeten IM (2003) Water in storage and approaches to groundwater management, high plains aquifer, 2000. US Geological Survey Circular 1243, 51 pp

Neuman SP, Witherspoon PA (1969) Applicability of current theories of flow in leaky aquifers. Water Resources Res (5):817-829

Pollock DW (1989) Documentation of computer programs to compute and display pathlines using results from the US Geological Survey modular three-dimensional finite-difference groundwater flow model, US Geological Survey Open-File Report 89-381

Rodrigues JD (1983) The Noordbergum effect and characterization of aquitards at the Rio Maior mining project. Ground Water 21(2):200-207 
Spalding RF, Watts DG, Schopors JS, Burbach ME, Exner ME, Poreda RJ, Martin GE (2001) Controlling nitrate teaching in irrigated agriculture. J Environ Quality 30(4):1184--1194

U.S. Geological Survey (2002) The High Plains Aquifer, http://wwwne.cr.usgs.gov/highplains/hpchar.html, accessed on January 12, 2003
Yeh WW (1986) Review of parameter identification procedures in groundwater hydrology: the inverse problem. Water Resources Res 22(2):95-108

Zlotnik VA, Zurbuchen BR (1998) Dipole probe: design and field applications of a single-borehole device for measurements of vertical variations of hydraulic conductivity. Ground Water 36(6):884-893 